\title{
SILIKĀTU MATERIĀLU INSTITŪTS LAIKA PERIODĀ NO 2008. LIDDZ 2018. GADAM
}

\author{
GUNDARS MEŽINSKIS ${ }^{1^{*}}$, ANDRIS CIMMERS ${ }^{2}$, \\ INNA JUHNEVIČA ${ }^{3}$ \\ ${ }^{1-3}$ Silikātu materiālu institūts, \\ Rīgas Tehniskā universitāte, Latvija
}

\begin{abstract}
Kopsavilkums. Šajā rakstā, izmantojot Latvijas uzṇēmumu datu bāzi, apzināti Latvijas Republikas uzṇēmumi, kuru tehnoloǵisko procesu pamatā ir silikātu, augsttemperatūras materiālu un neorganisko nanomateriālu tehnoloǵijas. Apkopotas un analizētas būtiskākās izmaiṇas pēdējās desmitgades laikā Rīgas Tehniskās universitātes Materiālzinātnes un lietišķās kuimijas fakultātes Silikātu, augsttemperatūras un neorganisko nanomateriālu tehnoloǵijas (SANNT) katedrā un Silikātu materiālu institūtā (SMI). Sniegtas ziṇas par SANNT katedrā sagatavotajiem bakalauru, maǵistru darbiem un aizstāvēto promocijas darbu skaitu. Apskatītas pētnieciskā darba finansējuma un zinātnisko pētījumu tematikas izmaiṇas laika periodā no 2008. līdz 2018. gadam. Definēti SMI stratēǵiskie mērḳi mācību un zinātniskajā darbībā nākamajiem 5 gadiem.
\end{abstract}

Atslēgas vārdi - RTU Silikātu materiālu institūts, mācību un zinātniskais darbs.

\section{Ievads}

2017. g. 1. oktobrī apritēja 70 gadi, kopš dibināta Rīgas Tehniskās universitātes (RTU) Silikātu tehnologijas katedra. RTU tipogrāfija 2007. g. publicēja monogrāfiju (brošūru), kurā tika sniegts pārskats par Silikātu materiālu institūtā paveikto mācību un zinātniskajā darbā 2002.-2007. g. [1]. Viens no 2007. g. publicētā darba mērķiem bija informēt Latvijas rūpniecības uzñēmumus par zinātnisko pētījumu tematiku un iegādātajām mūsdienu līmeṇa zinātniskās pētniecības iekārtām, sniedzot iekārtu iespēju aprakstus. RTU Materiālzinātnes un lietišķās ķīmijas

\footnotetext{
* Korespondējošais autors.

E-pasts: gundars.mezinskis@rtu.lv
} 
fakultātes 150 gadu jubilejas priekšvakarā tika publicēta kolektīvā monogrāfija, kurā SMI veltītajā nodaḷā īsumā apskatīta silikātu tehnoloǵijas kā studiju priekšmeta attīstība, sākot ar 1866./1867. mācību gadu Rīgas Politehnikuma Ķīmijas nodal̦a [2]. Monogrāfijā plašāk aprakstīti Silikātu tehnologijas katedras būtiskākie sasniegumi un notikušās izmaiṇas laika periodā kopš pēdējiem gadiem pirms Latvijas neatkarības atgūšanas, smagā desmitgade pēc tam, kā arī dots ieskats institūta attīstībā līdz pat 2013. g. [2]. Šĩs publikācijas mērḳis bija sniegt ieskatu Latvijas Republikas uzñēmumiem, kādas ir potenciālās darba vietas studentiem un absolventiem, kuri specializējušies Silikātu, augsttemperatūras materiālu un neorganisko nanomateriālu tehnologijās, kā arī apkopot un analizēt būtiskākās izmaiṇas pēdējās desmitgades laikā RTU Silikātu, augsttemperatūras un neorganisko nanomateriālu tehnologijas katedrā un Silikātu materiālu institūtā.

\section{Pārskats par Latvijas uzṇēmumiem silikātu, augsttemperatūras materiālu un neorganisko nanomateriālu tehnologiju jomās}

RTU Materiālzinātnes un lietišķās k̦īmijas fakultātes Silikātu, augsttemperatūras un neorganisko nanomateriālu tehnologijas (SANNT) katedra ir Silikātu materiālu institūta (SMI) struktūrvienība, kuras uzdevums ir "veidot un nodrošināt kvalitatīvu studiju procesu, dot studentiem un citiem interesentiem zināšanas, kas palīdz sasniegt nākotnes mērksus un pilnveidot talantus" [3]. Katedras nosaukums apliecina, ka studentiem ir iespējams gūt zināšanas silikātu un augsttemperatūras materiālu k̦īmijā un tehnologijā, kas ir Latvijas lielāko neorganisko materiālu un būvmateriālu ražotnu tehnologiju pamatā. SANNT katedras pasniedzēju izveidotie un reǵistrētie studiju kursi, kas atrodami RTU studiju kursu reǵistrā, liecina, ka studējošiem iespējams iegūt pamatzināšanas silikātu, augsttemperatūras materiālu un neorganisko nanomateriālu k̦īmijā un tehnoloǵijā, kā arī specializēties keramikas, saistvielu, stikla un neorganisko nanomateriālu ķīmijā un tehnologijā.

\section{A. Lursoft dati par Latvijas uzṇēmumiem silikātu, augsttemperatūras materiālu un neorganisko nanomateriālu jomās}

Lai noskaidrotu uzṇēmumus, kas darbojas Latvijas Republikā un kuru darbība saistīta ar silikātu, augsttemperatūras materiālu vai neorganisko nanomateriālu tehnologijām, tika izmantota Lursoft datu bāze. Saskaṇā ar Lursoft uzṇēmumu datu bāzi un nozaru NACE kodiem, Latvijā keramikas būvmateriālu ražošanā darbojas 11 uzñēmumi [4]. Savukārt citu porcelāna un keramikas izstrādājumu ražošanā - 55 uzṇēmumi [5]. 
Ar saistvielu (cementa, kal̦ka un gipša) NACE 23.5 ražošanu nodarbojas 5 uzñēmumi [6]. Ar betona, cementa un gipša izstrādājumu ražošanu nodarbojas 231 uzṇēmums [7], bet ar stikla un stikla izstrādājumu ražošanu (NACE 23.1) nodarbojas 74 uzn̄ēmumi [8].

Datu bāzē netika atrastas ziṇas par uznēmumiem, kas izmanto neorganisko materiālu nanotehnologijas, jo nav tāda NACE koda. Izmantojot atslēgas vārdu "nanotehnologija", atradām NACE kodam 72.11. atbilstošos uzṇēmumus, kas pamatā nodarbojas ar pētījumiem un izstrāžu veikšanu biotehnologijā. Izmantojot Lursoft uzñēmumu meklēšanas atlases nosacījumus vārdam "nano", atradām 42 uzṇēmumus [9]. Vairumā gadījumu firmu nosaukumos atrodamais vārds "nano" liecina vien par tā popularitāti klientu piesaistīšanai, nevis par nanotehnologiju izmantošanu kādu produktu ražošanā.

Diemžēl Lursoft datu bāzē iekl̦auto uzṇēmumu saraksts dod visai aptuvenu priekšstatu par potenciālajām darba vietām SANNT katedru absolvējušiem speciālistiem. Bieži datu bāzē atrastajiem uzṇēmumiem nav uzrādītas un nav atrodamas interneta mājas lapas, kas dotu pilnīgāku ieskatu uzñēmumu darbībā, produktos un izmantotajās tehnologijās. Daudziem uzṇēmumiem uzrādītas nelielas Valsts sociālās apdrošināšanas obligātās iemaksas. Tas norāda uz to, ka tie ir mikrouzñēmumi, kas visticamāk nepiesaistīs diplomētus speciālistus. Datu bāzē atrodami arī uzṇēmumi, kas jau pirms vairākiem gadiem likvidēti vai atrodas likvidācijas procesā. Bieži NACE kodā minētais apzīmējums "izstrādājumu ražošana" neietver konkrētā augsttemperatūras materiāla ražošanu, piemēram, stikla ieguvi kausēšanas procesā, bet saistāms ar iepirktā stikla iestrādi kādā citā materiālā (logi, durvis, dušas kabīnes, u. c.). Tādēl, raksta autori turpmākajā sadalıā, aprakstot konkrētajā nozarē aktīvos uzñēmumus un to sasniegumus, balstīsies ne vien uz datu bāzē atrodamo, bet arī internetā atrodamajām ziṇām un SANNT katedras pieredzi sadarbībā ar uzṇēmumiem.

\section{B. Vadošie silikātu un augsttemperatūras materiālu tehnoloǵiju uzṇēmumi Latvijā}

Ar silikātu un augsttemperatūras materiālu tehnologijām iegūst būvkeramikas, stikla, javu saistvielu materiālus. Ja nepiemin vairāk kā desmit sadzīves un dekoratīvo keramikas izstrādājumu ražotnes, noteikti jānosauc vadošais keramisko būvmateriālu (celtniecības k,ieǵel̦i, brugakmeṇi, apdares ķieǵeḷi) ražotājs Baltijā AS Lode, kura Ānes ražotnē ražo populāros celtniecības blokus KERATERM. SIA Ceplis ražo māla kieǵel̦us, kā arī maltu mālu mūrēšanai un māla-šamota sauso maisījumu augstas temperatūras izturīgas javas pagatavošanai.

Latvijā iegūst stikla un stikla šķiedras izstrādājumus, kā arī optiskos gaismas viḷnvadus. Lielākie šīs nozares uzṇēmumi ir AS Valmieras stikla 
škiedra, SIA Light Guide Optics International (iepriekš SIA Z-Light) un SIA Ceram Optec. Jāatzīmē, ka AS Valmieras stikla šķiedra ir vienīgais stikla šķiedras ražotājs Baltijas valstīs un viens no vadošajiem stikla šḳiedras ražotājiem Eiropā. AS Valmieras stikla šksiedra kopā ar tās meitas uzṇēmumiem, kas darbojas Latvijā, Lielbritānijā un Amerikas Savienotajās Valstīs, viedo Valmiera Glass grupu, kuras pamatdarbības virzieni ir stikla šķiedras pētniecība, stikla šķiedras produktu izstrāde, ražošana un pārdošana.

Pie materiāliem, kuru ražošanai izmanto silikātu un augsttemperatūras materiālu tehnoloǵijas, pieder arī javu saistvielas, tādas kā portlandcements, apdedzināti kaḷ k̦i un celtniecības gipsis. Javu saistvielu ražotnes Latvijā ir SIA Cemex, SIA Knauf un SIA Sakret.

Cemex ir vispasaules celtniecības materiālu kompānija, kas piegādā augstas kvalitātes produktus un nodrošina uzticamu servisu vairāk nekā 50 valstīs. Latvijā Cemex investēja vairāk par 310 miljoniem eiro un netālu no bijušās Brocēnu cementa rūpnīcas uzbūvēja Eiropā modernāko cementa rūpnīcu, kuras ekspluatāciju SIA Cemex uzsāka 2010. g. SIA Cemex ražo ne vien 4 tipu val̦ējo portlandcementu, 3 tipu portlandcementu maisos, bet arī dažādus betona veidus ražotnēs, kas atrodas Rīgā, Mārupes, Salaspils un Madonas novados. Jāatzīmē, ka ar gatavo betona maisījumu ražošanu Latvijā nodarbojas 26 uzn̄ēmumi.

Vācijas ǵimenes uzṇēmums Knauf kādreizējā Sauriešu būvmateriālu kombināta ražotṇu modernizācijā ieguldījis vairāk nekā 80 miljonus eiro. SIA Knauf, izmantojot Salaspils ǵipša atradnes un dažādus citus izejmateriālus, ražo sausās būves sistēmas ēkām, gipša un cementa apmetumus, flīžu līmes, celtniecības un sadzīves k̦īmijas izstrādājumus.

SIA Sakret dibināts 2003. g., izveidojot ražotni Rumbulā 2004. g. Pašreiz SIA Sakret ietilpst koncernā AS Sakret Holdings ar rūpnīcām Latvijā (SIA Sakret, SIA Sakret Plus), Lietuvā un Igaunijā, un ir lielākais sauso būvmaisījumu ražotājs Baltijā. Uznēēmums ražo dažāda lietojuma sausos maisījumus: betona, mūrjavas, cementa-kal,k,a un kal, ķa apmetumus, produktus ar pretsasalšanas piedevām u. c. materiālus būvniecībai.

AS Lode, AS Valmieras stikla škiedra, SIA Light Guide Optics International, SIA Cemex, SIA Knauf un SIA Sakret vadošajos amatos strādā Silikātu tehnologijas un SANNT katedras absolventi.

Pie javu saistvielu ražotnēm Latvijā nosacīti var pieskaitīt arī daudzskaitlīgās portlandcementa betona ražotnes. Balstoties uz betonu ražotṇu Lursoft reitinga rādītājiem (pēc 2016. g. pārskata datiem) un nodokḷu maksājumiem, valsts kopbudžetā 2017. g. pirmo vietu šo uzṇēmumu vidū ien,em SIA Transportbetons $M B$, otro - SIA CTB Betons, trešo - SIA ACB Betons.

Mūsuprāt, noteikti jāpiemin Latvijas uznēmēja Jāṇa Ošleja dibinātās kompānijas pasaules mēroga veiksmes stāsts. 1997. g. viṇš izveidoja 
SIA Primekss (apmaksātais pamatkapitāls - 1625474 EUR, reǵistrēts Uzṇēmumu reǵistrā 2016. g.) un 2008. g. AS Primeteh (apmaksātais pamatkapitāls - 99999 EUR, registrēts Uzṇēmumu reǵistrā 2015. g). SIA Primekss veic betona grīdu ieklāšanu un sienu apdari, izmantojot īpaši izturīgu betonu, savukārt AS Primeteh veic pētījumus un eksperimentālās izstrādes dabaszinātnēs un inženierzinātnēs. Abi šie uzñēmumi iekḷāvās 2008. g. izveidotajā holdingkompānijā SIA Primekss Group. Savukārt 2013. g. Šveicē tika reǵistrēta Primekss Group Switzerland AG [10], un šì uzṇēmuma mērksis ir iegūt, turēt, pārvaldīt un pārdot kapitāla daḷas iekšzemes un ārvalstu uzṇēmumos un finansēt Primekss grupas uzṇēmumus. Sabiedrība var dibināt filiāles Vācijā un ārvalstīs, kā arī piedalīties citos uzñēmumos. Primekss grupa savu darbību izvērsusi visās Skandināvijas un Baltijas valstīs, Polijā un izraudzīto franšīzes partneru valstīs visā pasaulē [11], [12]. Uzṇēmuma izcilo panākumu pamatā ir tā vispazīstamākais produkts - inovatīvs, uzlabots grīdu seguma materiāls PrimeComposite. Izstrādātā grīdu seguma materiāla pamatā ir betona mehāniskās stiprības palielināšana, pateicoties tērauda stiegrojuma stien,u nomaiṇai ar tērauda šksiedrām un uzṇēmuma laboratorijās (domājams, AS Primeteh) izstrādāto PrimeDC un PrimeFlow piedevu izmantošana [13]. Šis produkts saṇēmis dažādas godalgas, piemēram, Latvijas visinovatīvākais produkts 2010, balvas konkursos Eksporta un inovācijas balva 2009 [11], Visinovatīvākie betona pasaules produkti 2012 [13] un Eksportspējīgākais komersants 2016 [14]. Primekss grupas sasniegumi turpinās, jo pasaulē pirmā, patentētā sistēma ātrai un efektīvai daudzstāvu ēku celtniecībai, kas apvieno panel̦u, lokšnu konstrukcijas un tērauda šksiedru betona priekšrocības, betona nozares nozīmīgākajā pasākumā World Of Concrete 2018 saṇēma balvu Most Innovative Product Award 2018 [15]. To, ka Latvijas uzñēmumi var būt inovāciju un progresīvu tehnologiju līderi pasaulē, apliecina arī šā gada janvārī panāktā vienošanās par pētniecības projektu, kurā piedalīsies RTU, Latvijas Universitātes Cietvielu fizikas institūts, uzñēmums Primekss un Eiropas Kodolpētniecības centrs (CERN). Projektā notiks pētījumi materiālzinātnes jomā, lai izveidotu CERN vajadzībām betonu ar uzlabotām īpašībām un struktūru [16].

\section{Vadošie neorganisko nanomateriālu tehnologiiju uzṇēmumi Latvijā}

Neorganisko nanomateriālu tehnologiju attīstība Latvijā sākās pagājušā gadsimtā, kad 1962. g. tika nodibināts vakuuma metalizācijas projektēšanas birojs un kad 1971. g. tika uzsākta vakuuma pārklājumu sistēmu komerciāla ražošana [17]. Mūsdienās AS Sidrabe ir augsto tehnologiju ražotne, kas izstrādā un ražo unikālas vakuuma pārklājumu iekārtas atbilstoši individuālā pasūtījuma specifikācijai, konstrukcijai 
un tehnologijai, kā arī īpašas iekārtas, kas paredzētas nekonvencionālu procesu ieviešanai ražošanā. 2011. g. galvenie uzṇēmuma noieta tirgi bija ASV, Lielbritānija, Nīderlande, Japāna un Krievija [18]. 2015. g. Latvijas Zinātṇu akadēmijas zinātnisko sasniegumu konkursā Ievērojamākie sasniegumi Latvijas zinātnē 2015. gadā Latvijas universitātes Cietvielu fizikas institūta un AS Sidrabe zinātnieki un speciālisti uzvarēja lietišķās zinātnes sadaḷā par izstrādāto jauno magnetrona izsmidzināšanas tehnologiju un izveidoto daudzfunkcionālo iekārtu caurspīdīgu vadošu pārklājumu iegūšanai [19].

AS Neomat dibināta 1992. g. uz Latvijas ZA neorganisko materiālu speciālā tehnologiskā biroja bāzes. Šis birojs sāka darboties 1976. g., izgatavojot augsta līmeña materiālus bijušās PSRS militārajai un kosmosa rūpniecībai. AS Neomat izgatavo nanopulverus, ko tālāk var pielietot aviācijā un kosmosa tehnikā. Tā galvenie eksporta tirgi ir Vācija, Izraēla, Japāna, Krievija, Ukraina un ASV [20].

SIA GroGlass dibināta 2004. g. novembrī un ražošanu uzsāka 2008. g. [21]. Uzṇēmuma dạ̣as savā starpā dala Kipras Republikā registrēti uzñēmumi - Lindsell Enterprises Ltd. un Reardon Enterprises Ltd., kā arī Britu Virdžīnu salās reǵistrētie - Endeavor Capital Corp. un Target Capital Corp. [22]. Uzṇēmums izmanto AS Sidrabe izstrādātās magnetronās uzputināšanas iekārtas. SIA GroGlass ir progresīvo tehnologiju uzṇēmums, kas ražo dažādu oksīdu nanoizmēra optiskos vakuuma pārklājumus liela izmēra stiklam. Pašlaik tiek strādāts pie pilnīgi jaunas otrās ražošanas līnijas izstrādes, kurā tiks izmantotas kīimiskās pārklājumu iegūšanas tehnoloǵijas. SIA GroGlass antiatstarojošie un selektīvo filtru pārklājumi uz stikla tiek izmantoti gleznu ierāmēšanā, saules bateriju ražošanā, kā arī industriālajās siltumnīcās. Saražotie produkti tiek eksportēti uz vairāk nekā 45 valstīm. Pēdējo 5 gadu laikā SIA GroGlass saṇēmis balvas eksporta kategorijā Eiropas Biznesa balvas konkursā 2015/2016. g. [23], eksporta izcilības balvu The Red Jacket 2015. g. Latvijā [24], Best in Show balvu starptautiskajā izstādē Display Week 2014 Sandjego (ASV) [25].

SIA EUROLCDS rūpnīcu Ventspilī atklāja 2013. g. (dibinātāji: LC-TEC Display AB; Hornell Teknikinvest, Zviedrija; SIA Macro Rìga, Ogre; investīciju fonds BaltCap). SIA EUROLCDS ir Eiropas šk̦idro kristālu produktu izstrādes kompānija, kura attīsta unikālas funkcionalitātes bi-stabilu un ātra aizvara šķidro kristālu displeju, viedās stikla tehnoloǵijas un produktus transporta, medicīnas un aizsardzības jomas tirgiem [26]. SIA EUROLCDS sadarbojas ar augsto tehnologiju uzn̄ēmumu SIA HansaMatrix Ventspils, kas atrodas Ventspils Augsto tehnologiju parkā. SIA HansaMatrix Ventspils veic jaunu elektronisko produktu un sistēmu, datu tīklu iekārtu, lietu interneta (Internet of Things, ang. v.) un industriālo sistēmu izstrādi un darbojas arī citos augstas pievienotās vērtības tirgus 
segmentos [27]. SIA Lightspace Technologies ir viens no SIA EUROLCDS sadarbības partneriem [28]. Šis uzn,ēmums ir jaunuzñēmums (start-up, ang. v.) un kopš 1996. g. strādā pie tilpuma 3D attēlu veidošanas tehnologijas [28]. Oficiāli tas ir dibināts 2014. g., un tā darbības veids ir datoru un perifēro iekārtu ražošana [29]. Vēl agrāk, 1999. g., reǵistrēta AS HansaMatrix, kuras darbība ir saistīta ar elektronisko plašu ražošanu [30]. Kopumā jārunā par HansaMatrix uzñēmumu grupu. Tā veic jaunu elektronisko produktu un sistēmu izstrādi, to industrializāciju, kā arī sniedz integrētus ražošanas pakalpojumus klientiem, datu tīklu iekārtu, lietu interneta, industriālo sistēmu un citos augstas pievienotās vērtības tirgus segmentos [31]. HansaMatrix grupas vadītājs Ilmārs Osmanis informē, ka pēc 10 gadiem HansaMatrix redz sevi kā vienu no Baltijas un Ziemelvvalstu līderiem elektronisko sistēmu ražošanā [32].

Lursoft registrā 2013. g. ietverti vēl divi uzṇēmumi SIA Pogritech un SIA LED Chemicals, kas darbojas nanotehnologiju jomā. SIA Pogritech [33] izmanto neorganisko materiālu (karbīdu, nitrīdu, oksīdu pulveru, u. c.) augstas enerǵijas sasmalcināšanu, malšanu, lai aktivētu to virsmu [34]. Savukārt SIA LED Chemicals [35] ražos fosforescējošus neorganiskos pulverus un materiālus gaismu emitējošām diodēm [36]. Spriežot pēc Lursoft publicētajiem datiem, 2017. g. abiem šiem uzṇēmumiem nebija veiksmīgs.

SIA Naco Technologies izstrādājis šobrīd ātrāko fizikālo tvaika nogulsnēšanas metodi pārklājumu ieguvei. Tas dibināts 2010. g., izmantojot Komercializācijas Reaktora atbalstu (aǵentūru un mārketinga platforma jauniem, uz zinātni balstītiem uzṇēmumiem). Uzṇēmumi Imprimatur Capital, ZGI Capital un Proks Capital tika iesaistīti kā ieguldītāji un attīstītāji [37]. Automobiḷu un citu rūpniecības nozaru detalı piegādātāja Schaeffler grupa iegādājās SIA Naco Technologies 2015. g. [38] un 2017. g. pārsauca to par SIA Schaeffler Baltic, saglabājot Naco Technologies reǵistrācijas datumu Lursoft reǵistrā [39]. Maskavas Augsto tehnologiju neorganisko materiālu zinātniski pētnieciskā institūta profesors V. Mitins ir SIA Naco Technologies līdzdibinātājs un, mūsuprāt, rezultātus, kas likti pamatā SIA Naco Tehnologies izstrādātajai tehnologijai, ir publicējis jau 2006. g. [40]. SIA Naco Technologies vadītājs A. Parfinovičs atzinis, ka Latvija varētu kḷūt par vietu, kur tiek attīstītas augstās tehnoloǵijas, izmantojot Krievijas zinātnes pārstāvjus, kuri nerod atbalstu konkurētspējīgu eksporta produktu un nākotnes tehnoloǵiju attīstībā [41].

Latvijas nanotehnologiju zinātnes jaunuzñēmums SIA Nano Ray-T reǵistrēts 2015. g. [42]. Tā pamatdarbība saistīta ar augstas tīrības pakāpes oglekḷa nanocaurulīšu izmantošanu dažādiem tehniskiem pielietojumiem. 2016. g. uzñēmums kādai Francijas universitātei pārdeva savu pirmo k̦īmisko tvaika nogulsnēšanas reaktoru [43]. Reaktors paredzēts 
tādu oglekḷa nanocaurulīšu audzēšanai, kuru īpašības un struktūru iespējams mainīt atkarībā no pielietojuma.

Šajā rakstā nav pieminēti uzñēmumi, kas nodarbojas ar nanotehnologijām radīto produktu reklamēšanu un tirdzniecību, vai izmanto vārdu "nano", lai izraisītu interesi par kādu izstrādājumu. Raksta autoriem pārsteigumu izraisīja arī atradumi Lursoft datu bāzē 2017. g. augustā registrēts nodibinājums NANO FONDS [44], kas veicinās izglītību, jauno tehnologiju attīstību un to integrāciju sabiedrībā, kā arī 2018. g. martā dibinātā Latvijas Nanozinātnes un Nanotehnologijas Asociācija, kura nodarbosies ar Latvijas nanozinātnes un nanotehnoloǵijas juridisko un fizisko personu profesionālo, ekonomisko un tiesisko interešu aizstāvību, kā arī veicinās un sekmēs nanozinātnes un nanotehnologijas attīstību Latvijā un pasaulē [45]. Internetā neatradām informāciju, nedz par nodibinājuma NANO FONDS, nedz par Latvijas Nanozinātnes un Nanotehnologijas Asociācijas aktivitātēm.

Runājot par nanotehnologiju attīstību Latvijā, jāatzīmē, ka pagājušā gadsimta aston,desmito gadu beigās Rīgas Politehniskā institūta (pašreiz RTU) Silikātu materiālu tehnologijas katedrā (no 2007. g. SANNT katedra) pirmo reizi Latvijā tika uzsākti pētījumi mūsdienās visizplatītākās nanomateriālu sintēzes metodē - sola-gēla tehnologijas izmantošanā, lai iegūtu iepriekš neiegūstamus stiklveida materiālus un pārklājumus [46]-[48].

\section{Pārskats par mācību darbu no 2008. gada līdz 2018. gadam}

Atskatoties uz aizvadītajiem desmit mācību gadiem, kā nozīmīgāko notikumu jāatzīmē akadēmiskās maǵistru programmas "Materiālu nanotehnologijas" izstrādāšanu 2009. g. beigās un 2010. g. sākumā. Akadēmiskā maǵistru studiju programmai "Materiālu nanotehnologíjas" (45524) izsniegta licence ar Latvijas IZM Augstākās izglītības programmu licencēšanas komisijas 2010. g. 17. jūnija lēmumu. Programmas ietvaros iespējams specializēties 4 jomās: materiālu fizika un nanotehnologija; polimēru materiālu nanotehnoloǵija; neorganisko materiālu nanotehnologija un biomateriālu nanotehnologija. Studiju programmas mērkis ir sagatavot augsta līmeña speciālistus nanomateriālos un nanotehnoloǵijās, neorganisko, organisko un polimēru nanomateriālu, nanobiomateriālu jomās. Pēc studiju programmas sekmīgas apguves jaunie speciālisti pārzina šo nanomateriālu ieguves tehnologijas un prot tās pielietot zinātniski pētnieciskai darbībai [49]. Studiju virziens akreditēts lìdz 30.05.2019. [50].

Pārskatot mācību darbu, jāapskata SANNT katedrā sagatavoto un savus nobeiguma bakalauru un maǵistru darbus aizstāvējušo 


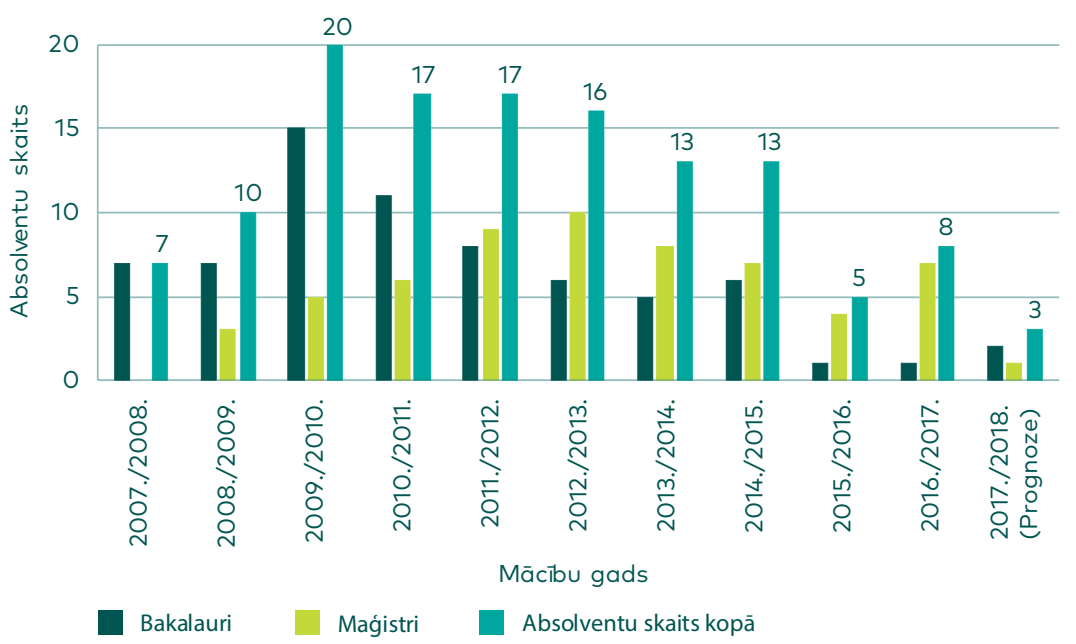

1. att. Silikātu, augsttemperatūras un neorganisko nanomateriālu tehnoloǵijas katedras absolventi 2008.-2017. g.

jauno speciālistu skaits (1. att.). Vislielākais absolventu skaits bija 2009./2010. mācību gadā - 15 bakalauri un 5 maǵistri. Līdz 2012./2013. mācību gadam pieauga maǵistru skaits, bet bakalauru skaits samazinājās. Pēdējos divos mācību gados ḷoti samazinājās bakalaura darbu aizstāvējušo studentu skaits, un 2017./2018. mācību gadā prognozējam vien divus bakalaura grādu un vienu maǵistra grādu ieguvušus katedras absolventus.

Pateicoties pieaugošajam zinātniskā darba finansējumam, kuru nodrošināja ERAF, EUREKA u. c. ārvalstu projekti, līdz pat 2014./2015. mācību gadam izdevās piesaistīt bakalaura un maǵistra līmeṇa studentus aktuālu zinātnisko pētījumu veikšanai. Līdz ar to studentiem tika dota iespēja ne vien izstrādāt nobeiguma darbus aktuālos pētījumu virzienos, izmantojot mūsdienu prasībām atbilstošas pētniecības iekārtas, bet arī saṇemt atlīdzību par paveikto darbu projektu ietvaros. Ievērojamais kritums sagatavoto speciālistu skaitam periodā no 2015./2016. līdz 2017./2018. mācību gadam pirmām kārtām saistāms ar sarukušo zinātnes finansējumu atbilstošajos periodos, jo studentu iesaiste projektos ḷauj vin,iem atteikties no darba ārpus MLK, līdz ar to arī aktīvāk ieklauties studiju procesos.

Augstākās kvalifikācijas speciālistu sagatavošanas dinamika (I. tabula) apstiprina gan to, ka tā saistāma ar zinātnes finansējuma apjomu Silikātu materiālu institūtā, gan to, ka promocijas darba izstrādāšanai minimālais nepieciešamais laiks ir 4-5 gadi. Visumā bilance ir pozitīva, jo aizstāvēšanas efektivitāte laika periodā no 2008. g. līdz 2018. g. ir 0,5.
Silikātu materiālu institūts laika periodā no 2008. līdz 2018. gadam 


\begin{tabular}{|c|c|c|c|c|c|c|c|c|c|c|c|}
\hline $\begin{array}{l}\text { n } \\
0 \\
0 \\
0\end{array}$ & $\begin{array}{l}\infty \\
\stackrel{0}{0} \\
\stackrel{N}{0}\end{array}$ & o̊ & $\stackrel{\circ}{\circ}$ & $\dot{\check{\sigma}}$ & $\stackrel{\text { ì }}{\text { ก }}$ & $\stackrel{\dot{m}}{\circ}$ & $\stackrel{\dot{j}}{\circ}$ & $\stackrel{\text { ம் }}{\text { D }}$ & $\stackrel{\dot{N}}{\circ}$ & 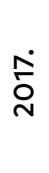 & 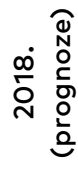 \\
\hline $\begin{array}{c}\text { Uznemtie } \\
\text { doktoranti }\end{array}$ & 2 & 1 & 1 & 3 & 4 & 3 & 1 & 3 & 2 & 2 & 1 \\
\hline $\begin{array}{c}\text { Aizstāvētie } \\
\text { promocijas } \\
\text { darbi }\end{array}$ & 2 & 0 & 0 & 1 & 1 & 0 & 0 & 3 & 2 & 1 & 2 \\
\hline
\end{tabular}

Saistībā ar mācību darbu katedrā jāuzsver, ka cieša sadarbība starp SMI un Latvijas uzṇēmumiem nodrošinās jaunu speciālistu sagatavošanu. Aizvadītajos gados tādi uzṇēmumi kā AS Valmieras stikla šķiedra, SIA Sakret, Light Guide Optics International Ltd. izrādīja interesi par jauno speciālistu sagatavošanu uzṇēmumu vajadzībām. Tas izpaudies gan uzṇēmumu stipendiju nodrošināšanā labākajiem bakalauru un maǵistru programmas studentiem, gan aktīvi piedaloties SMI un Materiālzinātnes un lietišşās ksīmijas fakultātes rīkotajos ikgadējos profesionālās orientācijas pasākumos: ievadlekcijas pirmā kursa studentiem, tikšanās ar Latvijas vidusskolu kīmijas skolotājiem un to apbalvošana, izlaidumu svinīgās sēdes u. c.

Iemesli krasajam SANNT katedras absolventu skaita samazinājumam 2015.-2018. m. g. var būt vairāki. Pirmām kārtām jāmin "demogrāfiskā bedre". 2005./2006. mācību gadā Latvijas augstskolās bija 131 tūkstotis studentu [51], bet 2016./2017. mācību gadā studējošo skaits samazinājās līdz 83 tūkstošiem [52]. Desmit gadus atpakal tika uzskatìts, ka augstākajām mācību iestādēm, lai tās nepārtrauktu savu darbību, atliek vai nu piesaistīt ārvalstu studentus, vai palielināt mācību maksu, un trešā iespēja ir prasît papildus līdzekḷus no valsts budžeta [51]. Pašreizējā situācija liecina, ka augstskolas, tajā skaitā arī RTU, izvēlējušās ārvalstu studentu piesaisti, jo 2016./2017. mācību gadā ārvalstu studentu skaits Latvijas augstskolās sasniedzis $10 \%$ no kopējā studentu skaita [53]. 2017./2018. mācību gadā RTU uzṇemti par 14 \% vairāk ārzemju studentu nekā 2016./2017. mācību gadā [54]. Ārzemju studenti Latvijas augstskolās galvenokārt piesaistīti no Vācijas (1182 studenti), Uzbekistānas (1057 studenti) un Indijas (750 studenti) [53].

Otrs iemesls ir vidusskolēnu vājās zināšanas k̦īmijā, fizikā un matemātikā, kas nosaka studentu lielo atbirumu pirmajos kursos un būtiski ierobežo to studentu skaitu, kas nokḷūst līdz bakalaura un maǵistra 
darbu izstrādei. Publikācijā "Dabaszinātnu izglītība Eiropā: valstu rīcībpolitika, prakse un pētījumi" [55] secināts, ka Eiropas valstīs, kur ir izstrādāta plaša dabaszinātṇu veicināšanas stratēgija, parasti tiek piedāvāta arī uz dabaszinātnēm orientēta karjeras izglītība skolēniem, un tikai dažās valstīs tiek îstenotas speciālas programmas un projekti, kas atbalsta apdāvinātu un talantīgu skolēnu tālāko izaugsmi dabaszinātṇu jomā. Spriežot pēc pirmā kursa studentu zināšanām ksimijā, fizikā un matemātikā, Latvijā nav panākts jūtams progress pēc Saeimas 2014. g. apstiprinātajām "Izglīīỉas attīstības pamatnostādnēm 2014.-2020. gadam" [56], lai gan pagājuši jau 4 gadi. Ar Valsts izglītības satura centra paveikto, lai realizētu Izglītības attīstības pamatnostādnes 2014.-2020. gadam saistībā ar diagnosticējošiem darbiem un centralizētiem eksāmeniem dabaszinātṇu mācību priekšmetos, var iepazīties šì centra interneta vietnē [57].

Trešais iemesls, kas pagaidām gan nav tik izteikts, bet tuvākajos gados var izvērsties ietekmes ziṇā līdzīgs "demogrāfiskai bedrei", ir zemais atalgojuma līmenis augstskolu mācību spēkiem. Tas izsauc mācību spēku aiziešanu uz vidējās izglītības iestādēm, komercuzṇēmumiem, valsts pārvaldes struktūrām. Latvijas finanšu un pārvaldes krīze (2008.-2010. g.) noteica būtisku un pagaidām neatgriezenisku valsts budžeta dotācijas samazinājumu augstākai izglīīibai, ko raksturo arī SANNT katedras mācību darba nodrošināšanai piešksirtā finansējuma izmainas 2007.-2018. g. (2. att.).

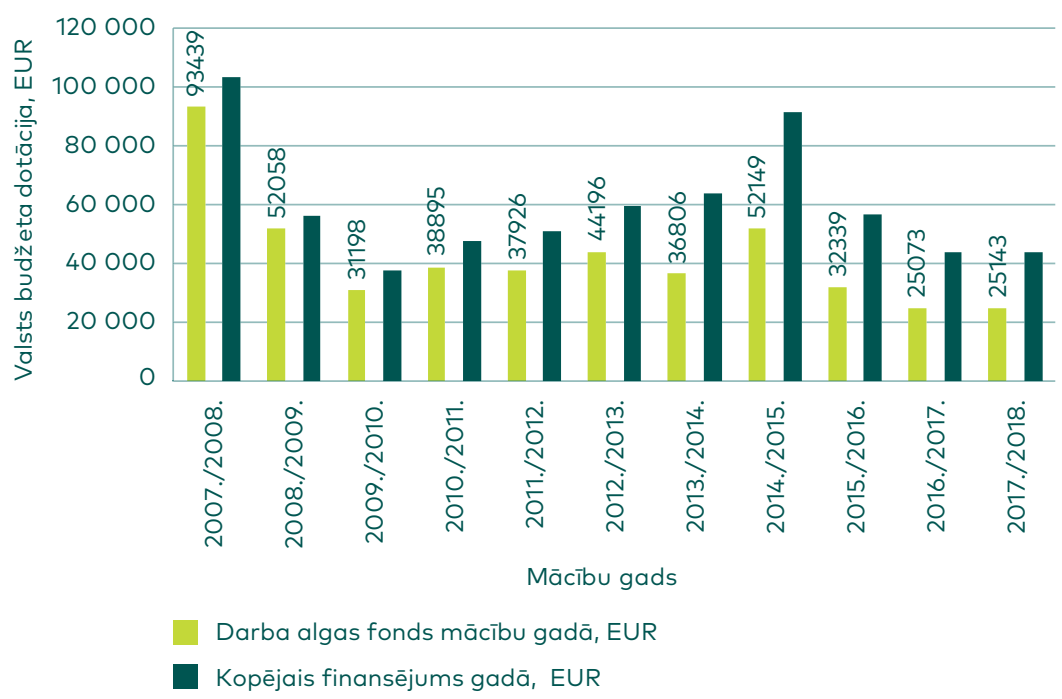

2. att. Silikātu, augsttemperatūras un neorganisko nanomateriālu tehnologiijas katedrai izdalītais finansējums 2008.-2018. g. 
Negatīvi vērtējama divu perspektīvu, nesen promocijas darbu aizstāvējušu (Andris Šutka (2013. g.) un Kaspars Mālnieks (2016. g.) pāriešana darbā uz 2017. gada janvārī nodibināto Materiālzinātnes un lietišķās kīimijas fakultātes Funkcionālo materiālu tehnologiju laboratoriju. Šĩs laboratorijas izveidi atbalstīja RTU Zinātṇu prorektors T. Juhna. Mūsuprāt, tas lāgā nesaskan ar RTU konsolidācijas ideju. Minēto bijušo SMI darbinieku pāriešana uz Funkcionālo materiālu tehnologiju laboratorija saistīta ar ievērojami augstāka atalgojuma piedāvājumu.

\section{Pārskats par zinātnisko darbu no 2008. gada līdz 2017. gadam}

Laika periodā no 2007. līdz 2012. gadam SMI zinātnisko pētījumu pamatvirziens bija silikātmateriālu (keramika, stikls, saistvielas) un augsttemperatūras nemetālisko materiālu k̦īmija un tehnologijas pamatu izstrādes. Augsta līmeña zinātniskie pētījumi tika uzsākti solagēla tehnoloǵijā un nanomateriālu tehnologiijās. Galvenais finansējuma avots zinātnisko pētījumu veikšanai sākot no 2010. gada bija ERAF projekti.

SMI zinātniski pētnieciskā darba finansējuma izmaiṇas laika periodā no 2008. gada līdz 2018. gadam liecina, ka Latvijas Zinātnes Padomes grantu līdzekḷi vairs nebija pieejami. Sākot ar 2013. g. RTU pētniecības projekti nozīmīgu pienesumu SMI finansēm deva vien 2008. un 2009. gadā (3. att.). Vislielāko finansējuma apjomu nodrošināja Valsts pētījumu programmas kā arī ERAF, EUREKA un citi ārvalstu projekti. Nozīmīgs rādītājs institūta finansējumā ir bāzes finansējuma apjomam, kas no 2014. gada pieaug, norādot uz zinātniskā darba kvalitātes pieaugumu.

Paredzot, ka, beidzoties ERAF projektu finansējumam 2014.-2015. g. būtiski pazemināsies finansējums zinātnei, tika mainīta SMI taktika finanšu līdzekḷu ieguvei. Galvenie pasākumi šīs taktikas realizācijā bija palielināt zinātnisko publikāciju kvalitāti (tādejādi paaugstinot to citējamību), palielināt ar Latvijas uznēmumiem noslēgto līgumdarbu skaitu, palielināt PLE zinātnē nodarbinātajiem SMI speciālistiem, kā arī pievērst uzmanību zinātnisko pētījumu valorizācijai. Minēto pasākumu realizācija ḷāva palielināt ienākumus no izpildītajiem līgumdarbiem no 6869 EUR 2015. g. uz 13694 EUR 2016. g. Savukārt 2017. g. ieṇēmumi no līgumdarbiem samazinājās līdz 11170 EUR. Šie pasākumi panāca bāzes finansējuma pieaugumu no 80508 EUR 2015. g. līdz 129051 EUR 2017. g. (3. att.). Šo pasākumu ietvaros tika piešksirtas prēmijas izcilākajiem zinātnisko publikāciju un līgumdarbu piesaistītājiem.

2008.-2017. g. iekārtu iegādei, izmantojot SMI zinātniskās darbības rezultātā iegūtos līdzekḷus, izlietoti 1252525 EUR. SMI zinātniskajā un 
mācību darbā nozīmīgākās iekārtas tika iegādātas 2009. g. un 2013. g. Tad sākām izmantot slāpekḷa adsorbcijas porozimetru, dzīvsudraba analīzes iekārtu, dilatometru, bīdes un statistiskās slodzes mērīšanas

800000

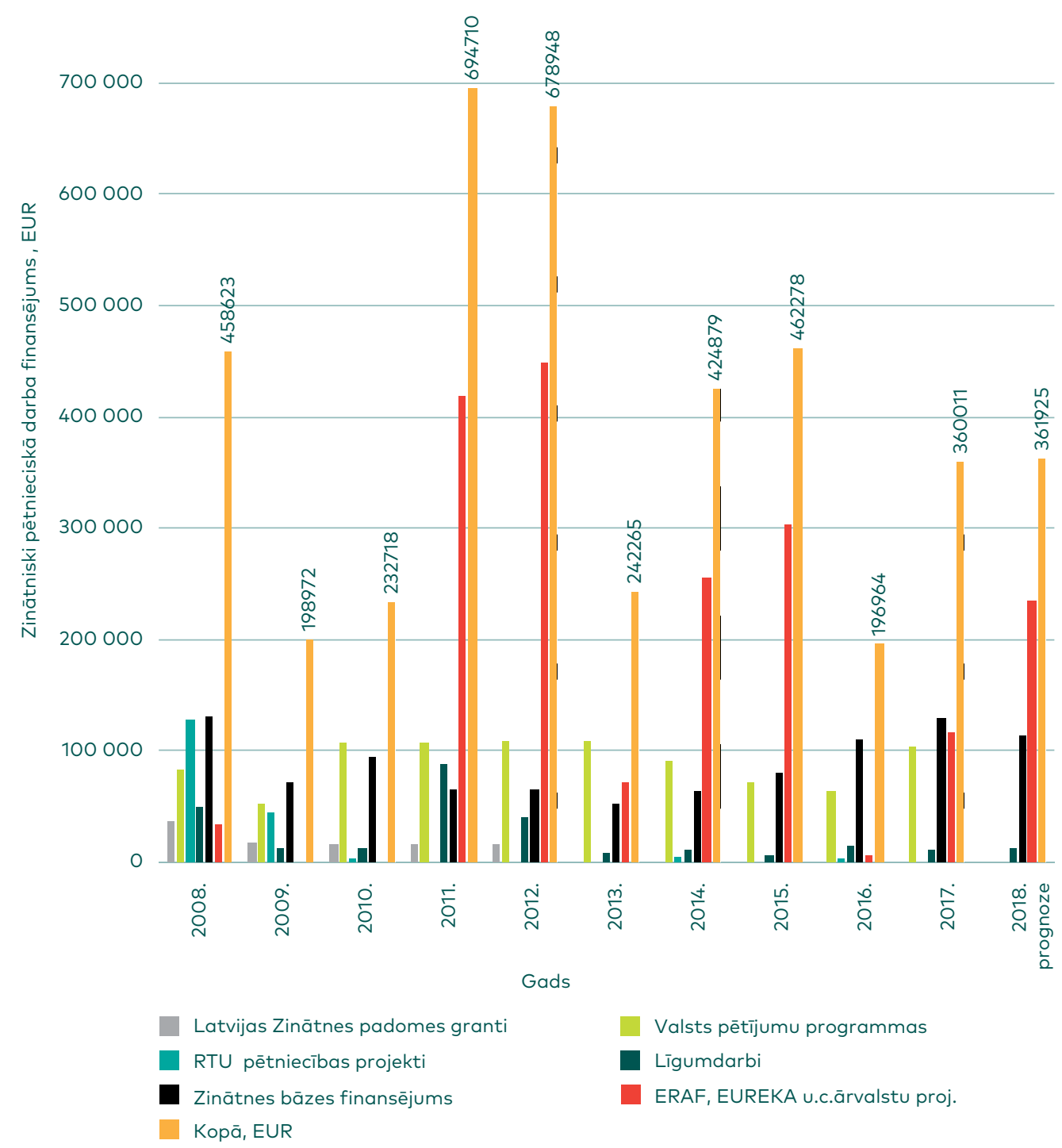

3. att. Silikātu materiālu institūta zinātniski pētnieciskā darba finansējums laika periodā no 2008. līdz 2018. gadam. Zinātnes bāzes finansējums uzrādīts ieskaitot snieguma finansējumu. 
iekārtas un augstas izšķirtspējas lauka emisijas (Šotki) skenējošo elektronu mikroskopu FEI Nova NanoSEM 650. Pārējo iegādāto iekārtu kopējā vērtība bija no 23000 EUR līdz 68000 EUR. Iznēmums bija 2008. g. un 2010. g., kad iegādāto iekārtu vērtība nepārsniedza 15000 EUR.

Izvēloties iegādājamās iekārtas, tika paredzēts, ka to izmantošana uzlabos mācību darba kvalitāti, kā arī zinātniskā darba kvalitāti. Zinātniskā darba kvalitāte saistāma ar to publikāciju skaita pieaugumu, kas tiek izmantotas RTU bāzes finansējuma aprēķinam institūtiem. 4. att. pierāda to, ka mūsdienīgu iekārtu iegāde 2009. g. un 2013. g. būtiski veicinājusi publikāciju pieaugumu zinātniskajos žurnālos, kas indeksēti SCOPUS datu bāzē. To skaits kopš 2010. g. pieaudzis 2 līdz 2,5 reizes.

Lielākā SMI bagātība ir kvalificēts personāls. Zinātnisko darbinieku personāla atjaunināšanas procesā, pateicoties pieejamajam bāzes

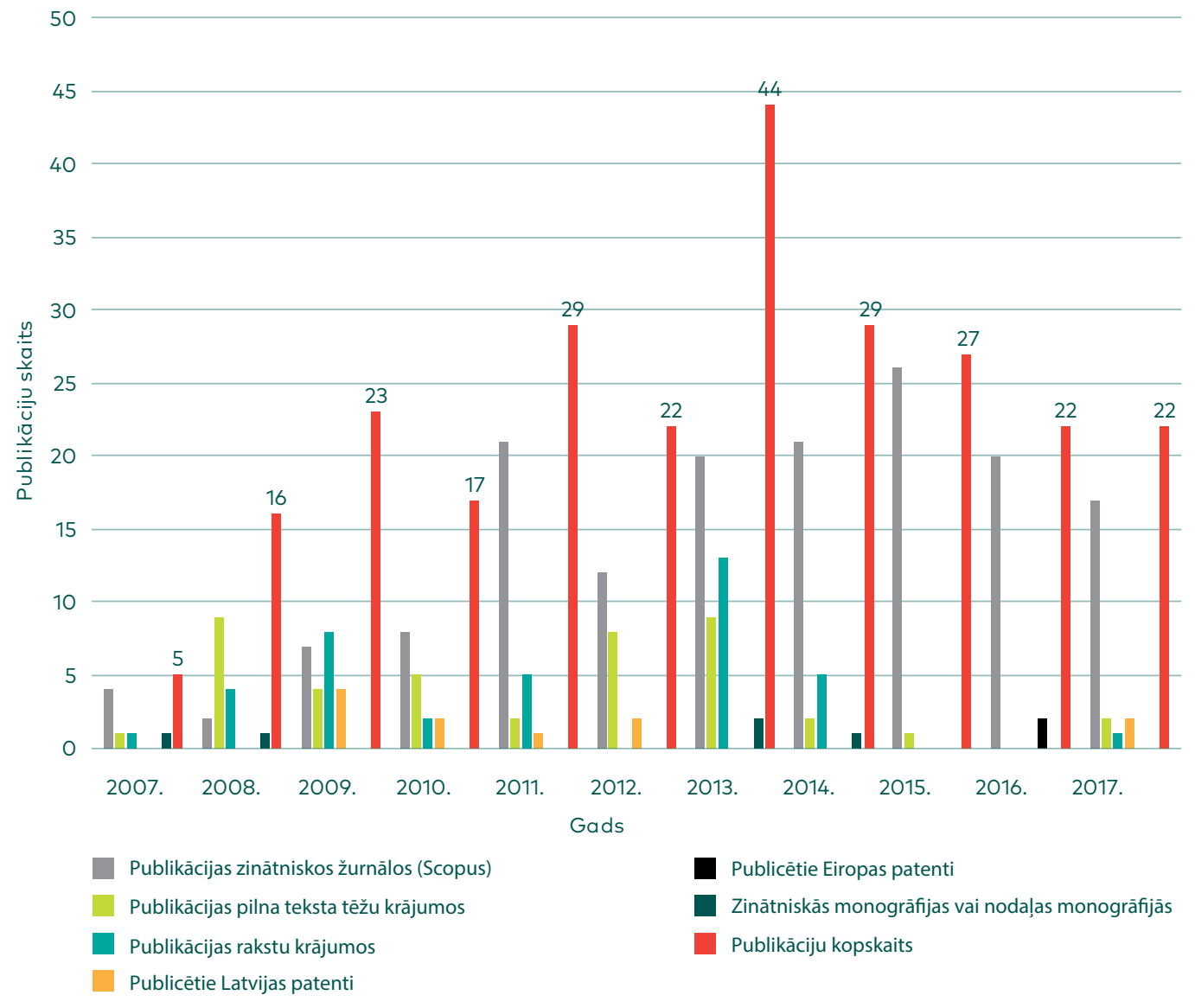

4. att. Silikātu materiālu institūta publikācijas no 2007. g. līdz 2017. g. 
finansējumam, novērojamas pozitīvas tendences, neskatoties uz to, ka aizvadītajā laika periodā zemā atalgojuma dēḷ no SMI aizgājuši 2 asociētie profesori (L. Krāǵe, I. Šperberga), 4 pētnieki (I. Zaķe-Tiḷuga, A. Hmel,ovs, A. Šutka, K. Mālnieks).

SMI šobrīd iekḷautas 4 struktūrvienības: Stikla un keramikas laboratorija (1990. g.); Akmens materiālu konservācijas un restaurācijas centrs (1995. g.); Materiālu virsmas morfologijas un struktūras analīzes laboratorija (2007. g.); Nanodal̦inuu un nanomateriālu k,īmiskās tehnologijas laboratorija (2007. g.). SMI atbalsta RTU Silikātu materiālu testēšanas laboratorijas (1999. g.) darbību, sedzot infrastruktūras izmaksas un nodrošinot pieeju pētnieciskajām iekārtām.

Iepriekšējo gadu attīstības pamatā bija sekojoši zinātniskās darbības virzieni (II. tabula).

II. tabula

SMI zinātniskās darbības virzieni 2012.-2016. g.

- Nanodaḷinu un nanomateriālu k̦īmiskā tehnoloǵija (prof. Gundars Mežinskis)

- Sola-gēla tehnoloǵija (prof. Gundars Mežinskis)

- Būvkeramika un ugunsizturīgie porainie keramiskie materiāli (asoc. prof. Visvaldis Švinka)

- Neorganiskās saistvielas, akmens materiālu korozija un restaurācija (asoc. prof. Linda Krāǵe).

- Oksīdu un jaukta sastāva keramikas materiāli (vad. pētn. Gaida Sedmale)

- Stiklveidīgo materiālu kīimija un tehnoloǵija (vad. pētn. Janīna Sētina)

Sakarā ar Materiālzinātnes un lietišķās k,īmijas fakultātes jauno zinātnisko virzienu noteikšanu un SMI personāla sastāva izmaiṇām no 2017. gada tika izmainīti SMI zinātniskās darbības virzieni (III. tabula).

III. tabula

SMI zinātniskās darbības virzieni sākot no 2017. g.

- Starpfāžu un robežprocesu principu izstrāde mikro-, submikro- un nanolīmenī heterogēniem, funkcionāliem neorganiskiem pārklājumiem un kompozītiem (prof. G. Mežinskis)

- Porainu oksīdu materiālu ieguves tehnoloǵiju izstrāde un pilnveide filtru un katalītisko materiālu izstrādei (asoc. prof. R. Švinka, asoc. prof. V. Švinka)

- Latvijas derīgo izrakteṇu izmantošana jaunu produktu ar augstu pievienoto vērtību ražošanai (asoc. prof. G. Sedmale)

- Jaunu un uzlabotu neorganisko saistvielu izstrāde un akmens materiālu korozijas un restaurācijas pētījumi (vad. pētn. I. Vītina) 
SMI nākotnes attīstību nosaka izvirzītie stratēgiskie mērḳi mācību un zinātniskajā darbā (IV. tabula).

SMI stratēǵiskie mērḳi mācību un zinātniskajā darbā 2018.-2023. g.

\begin{tabular}{|c|}
\hline Stratēǵiskie mērḳi mācību darbā \\
\hline $\begin{array}{l}\text { - Nodrošināt pakāpenisku mācību personāla atjaunināšanas procesu, } \\
\text { piesaistot jaunos mağistra un doktora grādu ieguvušos speciālistus } \\
\text { mācību procesam, un veicinot vecāka gadagājuma pasniedzēju aktīvu } \\
\text { piedalīšanos zinātniskajā darbā un pasākumos, kas virzīti uz profesionālās } \\
\text { kvalifikācijas paaugstināšanu mūža garumā, tai skaitā Latvijas } \\
\text { būvmateriālu rūpniecībā strādājošajiem speciālistiem; } \\
\text { - } \quad \text { Nodrošināt pasaules līmeṇa speciālistu sagatavošanu silikātu, } \\
\text { augsttemperatūras un neorganisko nanomateriālu kīimiskajā tehnoloǵijā; } \\
\text { - Veidot regulāru sadarbību ar Eiropas Savienības augstskolu } \\
\text { pasniedzējiem un zinātnisko centru speciālistiem, veicinot studentu un } \\
\text { pasniedzēju apmaiṇu ERASMUS programmas ietvaros; } \\
\text { - Popularizēt silikātu, augsttemperatūras un neorganisko nanomateriālu } \\
\text { kīimiskās tehnoloǵijas lomu Latvijas ekonomiskajā attīstībā. }\end{array}$ \\
\hline
\end{tabular}

Stratēǵiskie mērḳi zinātniskajā darbā

- Nodrošināt jaunu zinātnisko virzienu izveidi, kuru vadību realizētu jaunie, doktora grādu ieguvušie speciālisti.

- Nodrošināt augstas zinātniskās ietilpības pētījumu veikšanu silikātu, augsttemperatūras materiālu un neorganisko nanomateriālu kịimiskajā tehnoloǵijā.;

- Nodrošināt Latvijas uzṇēmumu atbalstīšanu tehnoloǵiskā pilnīguma un ražoto produktu zinātṇu ietilpības paaugstināšanā;

- Uz SMI laboratoriju bāzes izveidot Baltijas valstīs atzītu neorganisko materiālu pētījumu centru;

- Izveidot un akreditēt Latvijas nacionālajā akreditācijas sistēmā Silikātu materiālu un nanomateriālu testēšanas laboratoriju.

Mūsdienu situācija Latvijas augstākajā izglītībā un zinātnē viennozīmīgi parāda, ka nepieciešamas kardinālas izmaiṇas augstskolas pedagogu un zinātnieku pienācīga atalgojuma nodrošināšanā. Akadēmiskā personāla atlīdzībai jābūt tādai, kas atbilst ārvalstu akadēmiskajam personālam paredzētajam par darbu augstākās izglītības institūcijā, kas saskaṇā ar darbības programmas "Izaugsme un nodarbinātība" 8.2.2. specifiskā atbalsta mērķa "Stiprināt augstākās izglītības institūciju akadēmisko personālu stratēgiiskās specializācijas jomās" projektu iesniegumu atlases kārtas īstenošanas noteikumiem nedrīkst pārsniegt 4000 EUR mēnesī [58]. Savukārt, ja runājam par zinātniskā personāla 
atlīdzības apmēru, aug neticība, ka valdība varēs realizēt Zinātniskās darbības likuma 33. pantu, kas nosaka ikgadēju finansējuma pieaugumu zinātniskajai darbībai ne mazāku par 0,15 \% no iekšzemes kopprodukta, līdz valsts pieškirtais finansējums zinātniskajai darbībai sasniedz vismaz $1 \%$ no iekšzemes kopprodukta [59].

Augstākās izglītības padome kopā ar 14 citām ar augstāko izglītību un zinātni saistītām organizācijām nosūtījusi vēstuli augstākajām valsts amatpersonām, ierosinot 2019. g. noteikt par Latvijas Nacionālās augstākās izglītības un zinātnes sistēmas simtgades gadu, un pasludināt šīs jomas par prioritārām [60]. Augstākās izglītības darbiniekiem atliek cerēt, ka šis aicinājums ne vien tiks sadzirdēts, saprasts, bet arī būs par pamatu krīzes situācijas pārvarēšanai.

\section{Kopsavilkums}

RTU Materiālzinātnes un lietišksās k̦īmijas fakultātes Silikātu materiālu institūtā iespējams iegūt nepieciešamās zināšanas un praktiskās iemaṇas, lai Silikātu, augsttemperatūras un neorganisko nanomateriālu tehnologijas katedras absolventi varētu uzsākt darbu gan vadošos silikātu un augsttemperatūras materiālu tehnoloǵiju uzṇēmumos Latvijā, gan nanotehnologiju uzñēmumos, gan zinātniskās pētniecības institūcijās. Daḷa no vadošiem silikātu un augsttemperatūras materiālu tehnologiju uzṇēmumiem Latvijā atrodas ārvalstu uzṇēmēju valdījumā - AS Lode, SIA Cemex, AS Valmieras stikla šksiedra, SIA Knauf, SIA Ceram Optec, kas ierobežo Silikātu materiālu institūta sadarbības iespējas ar šiem uzñēmumiem, jo šìs kompānijas būtiskākos tiem nepieciešamos izpētes darbus veic ārvalstīs.

Nanotehnologiju jomā strādājošie uzṇēmumi iedalāmi tādos, kas dibināti pagājušā gadsimta septiṇdesmitajos un deviṇdesmitajos gados, un tādos, kas savu darbību uzsākuši pēdējos desmit gados. Vairums šo uzñēmumu izmanto neorganisko materiālu nanotehnologijas.

Par nozīmīgāko notikumu mācību darbā jāuzskata akadēmiskās maǵistru studiju programmas "Materiālu nanotehnologijas" izstrāde 2009.-2010. g. SANNT katedrā sagatavoto un savus nobeiguma bakalauru un maǵistru darbus aizstāvējušo jauno speciālistu skaits un tā dinamika ir saistīta ar Silikātu materiālu institūtā pieejamo zinātniskā darba finansējumu, pēdējos gados novērojamo studentu skaita samazinājumu un zemo atalgojuma līmeni mācību spēkiem.

SMI zinātnisko darbību pēdējos 10 gados pamatā nodrošināja Valsts pētījumu programmas, kā arī ERAF un EUREKA projekti. Zinātniskā darba kvalitāti būtiski uzlabojusi augstvērtīgu pētniecisko iekārtu iegāde, kurai izlietoti vairāk nekā 1200000 EUR. 
SMI mācību un zinātniskā darba pamatā jābūt mācību personāla atjaunināšanas procesam, sadarbībai ar Latvijas uzṇēmumiem un Eiropas Savienības augstskolu pasniedzējiem, kā arī zinātnisko centru speciālistiem.

\section{LITERATŪRAS SARAKSTS}

[1] G. Mežinskis un R. Švinka, Silikātu tehnoloǵijas katedrai 60: pārskats par mācību un zinātnisko darbu 2002.-2007. Rīga, Latvija: RTU Izdevniecība, 2007.

[2] G. Mežinskis un R. Švinka, "Silikātu materiālu institūts," no Rīgas Tehniskās universitātes Materiālzinātnes un lietišksās ķīmijas fakultātei - 150. Rīga, Latvija: RTU Izdevniecība, 2013, 293.-318. lpp.

[3] "Rīgas Tehniskā universitāte. Izcilības pieeja," rtu.lv [Online]. Available: https://files.rtu.lv/public/ortus/RTU_Izcilibas_pieeja.pdf. [Accessed May 25, 2018].

[4] “Keramikas būvmateriālu ražošana," lursoft.lv [Online]. Available: https://nace.lursoft.lv/23.3/keramikas-buvmaterialu-razosana/ companies/?vr=3\&old=0 [Accessed May 25, 2018].

[5] “Citu porcelāna un keramikas izstrādājumu ražošana," lursoft.lv [Online]. Available: https://nace.lursoft.lv/23.4/citu-porcelana-un-keramikasizstradajumu-razosana/companies/?vr=3\&old=0 [Accessed May 25, 2018].

[6] “Cementa, kal̦ka un gipša ražošana,” lursoft.lv [Online]. Available: https://nace.lursoft.lv/23.5/cementa-kalka-un-gipsa-razosana/ companies/?vr=3\&old=0 [Accessed May 25, 2018].

[7] "Betona, cementa un gipša izstrādājumu ražošana," lursoft.lv [Online]. Available: https://nace.lursoft.lv/23.6?vr=3\&old=0 [Accessed May 25, 2018].

[8] "Stikla un stikla izstrādājumu ražošana," lursoft.lv [Online]. Available: https://nace.lursoft.lv/23.1/companies?vr=3\&o=20 [Accessed May 25, 2018].

[9] “Uzṇēmumu meklēšana: 'nano'," lursoft.lv [Online]. Available: https:// www.lursoft.lv/exec?act=URCP\&ref=LurTop\&l=lv\&cp=3\&task=search\&r egcode $=\&$ CompanySearchForm $\% 5$ BcompanyName $\% 5 \mathrm{D}=$ Nano \&Compan ySearchForm\%5Bcountry\%5D=\&setm=ur\&general=Nano\&cid=LVA_NG_ PROD [Accessed May 25, 2018].

[10] "Primekss Group Switzerland AG," business-monitor.ch [Online]. Available: https://business-monitor.ch/en/companies/580243-primekss-groupswitzerland-ag [Accessed May 25, 2018].

[11] "Innovative_companies in Latvia. Latvijas investīciju un attīstības aǵentūra," liaa.gov.lv [Online]. Available: http://www.liaa.gov.lv/files/liaa/ attachments/innovative_companies_in_latvia.pdf [Accessed May 25, 2018].

[12] A. Sauka, Latvijas uzṇēmēju stāsti. Pasniedzējiem, pētniekiem un praktikiem. Riga, Latvia: Stockholm School of Economics in Riga, 2013. 
[13] “2012 Most Innovative Products - Entry: Primekss PrimeComposite," concreteconstruction.net [Online]. Available: http://www.concreteconstruction.net/products/primekss-primecomposite_o [Accessed May 25, 2018].

[14] "Konkursa "Eksporta un inovācijas balva 2016" laureāti," liaa.gov.lv [Online]. Available: http://www.liaa.gov.lv/lv/par-liaa/eksporta-un-inovacijas-balva-2016/laureati-2016 [Accessed May 25, 2018].

[15] "Industry Choice: PrīmXComposite-Filigran System," concreteconstruction.net [Online]. Available: http://www.concreteconstruction.net/products/industry-choice-primxcomposite-filigran-system_o [Accessed May $25,2018]$.

[16] "Latvijas uzṇēmēji pārliecinās par sadarbības iespējām ar CERN," em.gov. $l v$, Jan. 24, 2018. [Online]. https://www.em.gov.lv/lv/jaunumi/17782-latvijas-uznemeji-parliecinas-par-sadarbibas-iespejam-ar-cern [Accessed May 25, 2018].

[17] "Sidrabe. History," sidrabe.com [Online]. https://www.sidrabe.com/company/history.html [Accessed May 25, 2018].

[18] "Atzinība kategorijā "Eksportspējīgākais komersants 2011" lielo un vidējo komercsabiedrību grupā - Sidrabe, AS," liaa.gov.lv [Online]. http:// www.liaa.gov.lv/lv/as-sidrabe-2011 [Accessed May 25, 2018].

[19] “Ievērojamākie sasniegumi Latvijas zinātnē 2015. gadā," lza.lv [Online]. http://www.lza.lv/index.php?option=com_content\&task=view\&id=3008 \&Itemid=87 [Accessed May 25, 2018].

[20] “NEOMAT JSC," exim.lv [Online]. http://www.exim.lv/neomat [Accessed May 25, 2018].

[21] “Groglass. History," groglass.com [Online]. https://www.groglass.com/ about/history/ [Accessed May 25, 2018].

[22] "GroGlass valdē iecelts jauns valdes loceklis," klientuportfelis.lv, Feb. 2, 2018. [Online]. https://www.klientuportfelis.lv/lv/jaunumi/6234/groglass-valde-iecelts-jauns-valdes-loceklis [Accessed May 25, 2018].

[23] “RUBAN D'HONNEUR RECIPIENTS FOR 2015/16," businessawardseurope. com [Online]. https://www.businessawardseurope.com/index.php?/ $\mathrm{RDH} / 2015$ [Accessed May 25, 2018].

[24] "Eksporta izcilības balvas The Red Jackets pasniegtas 25 eksporta zīmoliem," db.lv, Oct. 22, 2015. [Online]. http://www.db.lv/zinas/eksporta-izcilibas-balvas-the-red-jackets-pasniegtas-25-eksporta-zimoliem-440043 [Accessed May 25, 2018].

[25] "DISPLAY WEEK 2014 INTERVIEWS," displayweek.org [Online]. http:// www.displayweek.org/2014.aspx [Accessed May 25, 2018].

[26] "Lightspace Technologies: Products \& Technologies," eurolcds.com [Online]. http://www.eurolcds.com [Accessed May 25, 2018].

[27] "HansaMatrix," hansamatrix.com [Online]. http://www.hansamatrix.com [Accessed May 25, 2018].

[28] "Lightspace Technologies," labsoflatvia.com [Online]. http://www.labsoflatvia.com/lv/start-up-/lightspace-technologies [Accessed May 25, 2018]. 
[29] “Lightspace Technologies, SIA," lursoft.lv [Online]. https://company.lursoft.lv/lightspace-technologies/40103758550 [Accessed May 25, 2018].

[30] "HansaMatrix, Akciju sabiedrība," lursoft.lv [Online]. http://company.lursoft.lv/lv/hanzas-elektronika/40003454390 [Accessed May 25, 2018].

[31] “HansaMatrix iek̦īājusi visu mantu," db.lv, Feb. 7, 2018. [Online]. http:// www.db.lv/zinas/hansamatrix-iekilajusi-visu-mantu-471686 [Accessed May 25, 2018].

[32] “HansaMatrix palielina ražošanas apjomus," ventasbalss.lv, Jan. 16, 2018. [Online]. https://www.ventasbalss.lv/zinas/brivosta/34993-hansamatrix-palielina-razosanas-apjomus $\% 20$ Avots $\% 20$ skat $\%$ C4\%ABts $\% 2030$. apr\%C4\%ABl\%C4\%AB [Accessed May 25, 2018].

[33] "Pogritech, Sabiedriba ar ierobezotu atbildibu," lursoft.lv [Online]. https://company.lursoft.lv/en/pogritech/40103636779 [Accessed May 25, 2018].

[34] "Pogritech. About us," pogritech.com [Online]. http://pogritech.com/ about-us/ [Accessed May 25, 2018].

[35] "LED Chemicals, SIA," lursoft.lv [Online]. https://company.lursoft.lv/lv/ led-chemicals/40103743165 [Accessed May 25, 2018].

[36] “Nano RAY-T, SIA," lursoft.lv [Online]. https://company.lursoft.lv/lv/nanoray-t/40103889000 [Accessed May 25, 2018].

[37] "Schaeffler acquires highly innovative development partner - Naco Technologies, in surface technology," blog.commercializationreactor.com [Online]. http://blog.commercialization reactor.com/2015/12/07/schaeffler-acquires-highly-innovative-development-partner-naco-technologies-in-surface-technology/ [Accessed May 25, 2018].

[38] "Schaeffler iegādājies Latvijas uzn̄ēmumu SIA Naco Technologies," $d b . l v$, Dec. 8, 2015. [Online]. http://www.db.lv/zinas/schaeffler-iegadajies-latvijas-uznemumu-sia-naco-technologies-442393 [Accessed May 25, 2018].

[39] "Iepriekšējie nosaukumi: SCHAEFFLER BALTIC, SIA," lursoft.lv [Online]. https://www.lursoft.lv/lapsaext?act=UR_NAMES\&code=010328848\&l=lv [Accessed May 25, 2018].

[40] V. S. Mitin, E. I. Sharipov, and A. V. Mitin, "High deposition rate magnetrons: key elements and advantages," Surface Engineering, vol. 22, no. 1, pp. 5-10, Feb. 2006. https://doi.org/10.1179/174329406x85038

[41] "Uzn̄ēmējs: Latvija var kḷut par augsto tehnoloǵiju attīstīšanas vietu," labsoflatvia.com, Apr. 29, 2016. [Online]. http://www.labsoflatvia.com/ lv/zinas/uznemejs-latvija-var-klut-par-augsto-tehnologiju-attistisanasvietu-2 [Accessed May 25, 2018].

[42] “Nano RAY-T," nanorayt.com [Online]. http://www.nanorayt.com/ [Accessed May 25, 2018].

[43] "LATVIAN NANOTECH STARTUP WINS FIRST DEAL," arcticstartup.com, Jun. 30, 2016. [Online]. http://arcticstartup.com/latvian-nanotech-reactor/ [Accessed May 25, 2018].

[44] “NANO FONDS, Nodibinājums," lursoft.lv [Online]. https://company.lursoft.lv/nano-fonds/40008246275 [Accessed May 25, 2018]. 
[45] “Latvijas Nanozinātnes un Nanotehnologiijas Asociācija” lursoft.lv [Online]. https://company.lursoft.lv/latvijas-nanozinatnes-unnanotehnologijas-asociacija/40008274673 [Accessed May 25, 2018].

[46] G. H. Mežinskis, U. Ja. Sedmalis, and Ju. V. Valinieks, "Rastvornaja i zol-gel tehnologii kak dispergacionnye i strukturu obrazujuŝie metody sinteza stekol," Izv. AN Latv. SSR, no. 5, pp. 525-531, 1986.

[47] G. H. Mežinskis, Ja. Ja. Bolšij, and U. Ja. Sedmalis, "Izučenie struktury i fiziko-himičeskih svojstv kadmij soderžaŝih stekol v zavisimosti ot metoda sinteza," Izv. AN Latv. SSR, no. 1, pp. 47-52, 1988.

[48] G. Mežinskis, “Thick Sol-Gel Coatings," Latvijas k̦īmijas žurnāls, no. 1 pp. 3-11, 1992.

[49] "Studiju programma: Materiālu nanotehnoloǵijas," rtu.lv [Online]. https://stud.rtu.lv/rtu/spr_export/prog_pdf_lv.100 [Accessed May 25, 2018].

[50] "Akreditētie studiju virzieni un programmas," aic.lv [Online]. http:// www.aic.lv/portal/aikna/akreditetie-studiju-virzieni-un-programmas [Accessed May 25, 2018].

[51] A. Pelane, "Demogrāfiskais iekritiens," lvportals.lv, Jan. 30, 2008. [Online]. http://m.lvportals.lv/visi/likumi-prakse?id=170005\&size=1\&size=2 [Accessed May 25, 2018].

[52] A. Pelane, "Skaiți un fakti - rūkošo studentu skaitu augstskolas mēgina kompensēt ar ārzemniekiem," Ism.lv, Jan. 30, 2008. [Online]. https://www.lsm.lv/raksts/zinas/latvija/skaitli-un-fakti--rukosostudentu-skaitu-augstskolas-megina-kompenset-ar-arzemniekiem. a221344/\#comments-article-221344 [Accessed May 25, 2018].

[53] “2016./2017. akadēmiskajā gadā Latvijas augstskolās uzṇemti 28588 studenti" izm.gov.lv [Online]. http://www.izm.gov.lv/images/izglitiba_augst/ Parskats2016vizualis.pdf [Accessed May 25, 2018].

[54] “RTU šogad rekordliels uzn,emto ārvalstu studentu skaits," rtu.lv, Feb. 22, 2018. [Online]. https://www.rtu.lv/lv/universitate/masu-medijiem/ zinas/atvert/rtu-sogad-rekordliels-uznemto-arvalstu-studentu-skaits [Accessed May 25, 2018].

[55] "Dabaszinātṇu izglītība Eiropā: valstu rīcībpolitika, prakse un pētījumi," eacea.ec.europa.eu, 2012. [Online]. http://eacea.ec.europa.eu/education/ eurydice/documents/thematic_reports/133LV.pdf [Accessed May 25, 2018].

[56] "Par Izglīî̄bas attīstības pamatnostādṇu 2014.-2020. gadam apstiprināšanu," Latvijas Vēstnesis, May, pp. 2014/103.1, 2014.

[57] A. Cābelis, "Pārbaudes darbu paraugi," visc.gov.lv, Aug. 31, 2017. [Online]. http://visc.gov.lv/vispizglitiba/eksameni/paraugi.shtml [Accessed May 25, 2018].

[58] "Darbības programmas "Izaugsme un nodarbinātība" 8.2.2. specifiskā atbalsta mērksa "Stiprināt augstākās izglītības institūciju akadēmisko 
personālu stratēgíiskās specializācijas jomās pirmās, otrās un trešās projektu iesniegumu atlases kārtas īstenošanas noteikumi," m.likumi.lv, Jan. 9, 2018. [Online]. https://likumi.lv/doc.php?id=296513 [Accessed May 25, 2018].

[59] "Par jauna augstākās izglītības finansēšanas modeḷa ieviešanu Latvijā,” m.likumi.lv, Jun. 29, 2015. [Online]. https://m.likumi.lv/doc. php?id=274944\# [Accessed May 25, 2018].

[60] I. Kuzmina, "Pēc valsts simtgades aicina atzīmēt augstskolu un zinātnes simtgadi," la.lv, Feb. 6, 2018. [Online]. http://www.la.lv/izglitibunosauks-par-prioritaru-un/ [Accessed May 25, 2018].

Gundars Mežinskis, Dr. habil. sc. ing. (1998. g.), Rīgas Tehniskās universitātes profesors (2000. g.), RTU Silikātu materiālu institūta direktors (2000. g.) un Silikātu, augsttemperatūras un neorganisko nanomateriālu tehnologijas katedras vadītājs (2007. g.). Vinš̌ ir 248 zinātnisko publikāciju autors, kā arī daudzu bakalaura, maǵistra un doktora disertāciju zinātniskais vadītājs.

E-pasts: gundars.mezinskis@rtu.lv

ORCID: 0000-0002-6030-4247

Andris Cimmers, Dr. sc. ing. (zin. kand. disertācija 1987. g., pielīdzināta Dr. sc. ing. 1992. g.), RTU Silikātu materiālu institūta direktora vietnieks (2010. g.). Viṇa interešu lokā ir jaunu keramisko materiālu tehnologijas un stiklveida pārklājumu metālam tehnologijas. Viṇš ir 82 zinātnisko publikāciju un izgudrojumu autors, kā arī vairāku bakalaura un magistra darbu zinātniskais vadītājs.

E-pasts: andris.cimmers@rtu.lv

ORCID: 0000-0002-9141-1280

Inna Juhṇeviča, Dr. sc. ing. (2003. g.), Rīgas Tehniskā universitāte. Kopš 1998. g. viṇa ir vadošā pētniece un asociētā profesore Rīgas Tehniskā universitātes Silikātu materiālu institūtā. 26 zinātnisku publikāciju autore, vairāku bakalauru un maǵistru darbu zinātniskā vadītāja.

E-pasts: inna.juhnevica@rtu.lv

ORCID: 0000-0003-0061-7572

Gundars Mežinskis, Andris Cimmers, Inna Juhṇeviča.

\section{Institute of Silicate Materials between 2008 and 2018.}

Keywords - Riga Technical University, Institute of Silicate Materials, research, teaching.

In this article, information about Latvian companies whose technologies are based on silicate, high temperature materials and inorganic nanomaterials was gathered from a data base of commercial companies Lursoft. The most significant changes that occurred at the Department of Silicate, High Temperature and Inorganic Nanomaterials (SHTIN) and Institute of Silicate Materials (ISM) of the Faculty of Materials Science and Applied Chemistry, Riga 
Technical University are summarized and analysed. Information about the number of bachelor's, master's degree theses, and doctoral theses defended at the department of SHTIN is provided. The changes in the research funding and scientific research topics during the period from 2008 to 2018 are considered. The strategic objectives of the ISM for teaching and research work for the next 5 years are defined.
Silikātu materiālu institūts laika periodā no 2008. līdz 2018. gadam 